\title{
The Role of Risk Culture in Enterprise Risk Management Implementation
}

\author{
Mohamed Santigie Kanu ${ }^{1}$ \\ ${ }^{1}$ Ph.D. Student, Open University of Switzerland, Switzerland \\ Correspondence: Mohamed Santigie Kanu, Ph.D. Student, Open University of Switzerland, Switzerland. E-mail: \\ ris1310792@ous.academy \\ Received: August 28, 2020 \\ Accepted: September 14, 2020 \\ Online Published: October 20, 2020 \\ doi:10.5539/ijbm.v15n11p13 \\ URL: https://doi.org/10.5539/ijbm.v15n11p13
}

\begin{abstract}
Enterprise Risk Management (ERM) and risk culture academics and practitioners have argued that they are inherently related without empirical evidence. They continue to advocate for their implementation by firms to face the dynamic business environment with certainty. The lack of empirical evidence to underpin this relationship partly contributes to their fragmented implementation and the lack of proper attention to risk culture in ERM implementation. The challenge in measuring these two abstract concepts contributes to their dichotomous measures in the literature, with most studies concentrated in the developed economies. The study objective is to provide a comprehensive measurement of the two constructs and empirically determine their relationship in the less-researched context of Africa. The study results empirically confirm risk culture and ERM to have a significant positive relationship. A firm's size and financial leverage were found to be significant determinants for ERM implementation, whereas capital opacity, financial slack, and board composition are not. Organizational leaders are advised by the study not to treat risk culture and ERM as substitutes but as complements. A sound risk culture provides a solid base for ERM implementation. Risk culture should be managed and developed in full alignment with the risk appetite and the ERM framework to improve organizational performance. These shall enable the promotion of a risk-aware culture and ingraining risk-related measures into performance management that help drive the organization forward. The constructs measures presented in the study can be used by academics and risk practitioners to determine the level of risk culture and ERM implementation in organizations.
\end{abstract}

Keywords: enterprise risk management, risk culture, PLS-SEM

\section{Introduction}

ERM is a recent phenomenon whose research domain has not reached the required maturity level (Viscelli, Beasley \& Hermanson, 2016; Beasley, Branson \& Pagach, 2015; Hoyt \& Liebenberg, 2015). It is an evolving discipline (Mikes \& Kaplan, 2015) whose set of practices should not be viewed as evolving that will eventually become codified (Jankensgård, 2019). Research direction on the concept is still at an infancy stage (Bromiley, Mcshane, Nair \& Rustambekov, 2015). It has mostly been directed to the factors driving its implementation (Aleisa, 2018; Bohnert, Gatzert, Hoyt \& Lechner, 2018; Gatzert \& Martin, 2015) and its relationship with firm performance (Anton 2018; Bohnert et al., 2018; Alawattegama 2018; Sayilir \& Farhan 2017) with mixed results. Recent research direction is on the mediating role of strategic planning on its relationship with firm performance (Sax \& Andersen 2019), development of measurement scales for the construct (Marahun, Atan, Yusuf \& Said, 2018), theoretical analysis of the ERM concept (Jankensgård, 2019, Mikes \& Kaplan, 2015), a research opportunity in the management domain (Bromiley et al., 2015). The difficulties encountered in these streams of research are the unavailability of a single definition and framework of the ERM concept (Kopia, Just, Geldmacher \& Bubian, 2017; Mikes \& Kaplan, 2015). The lack of a research criterion (Waweru \& Kisaka, 2013) and a consensus on what ERM is all about and the constituents of its principal components (Bromiley et al., 2015; Lunqvist, 2014) also limits ERM research.

The aftermath of the 2008 global financial crises caused an increase in the development of risk cultures in organizations (Marshall, 2016). It has also caused financial authorities to demand financial institutions for guidance on risk management, including risk culture, to regain their financial stability (Bott \& Milkau, 2018). When organizations have a good risk culture and a robust risk governance framework, consistent support is 
provided for appropriate risk awareness, behavior, and judgment about risk-taking Financial Stability Board (FSB, 2014). The United Kingdom Institute of Risk Management (IRM) (2012) states that an organization's leadership should embed its risk management framework into its culture, processes, and structure if they are to realize a sound ERM.

An organization can have an overall positive culture but lacks a sound risk culture because most of the employees see risk management as a compliance issue and not a means of arriving at sound business decisions. As Ian Laughlin (former deputy chair of Australian Prudential Regulatory Authority-APRA) once said, if culture is "the way we do things around here," then risk culture is "the way we do risk around here." Risk culture can, therefore, be regarded as the impact of organizational culture on risk management. Well-designed and implemented risk cultures provide the cultural context in which risk management processes flourish (Marshall, 2016). ERM requires proactive participation of all employees within the organization in responding to risk. Risk cultures can control organizational risk-taking and can protect against reckless risk-taking by employees. Risk culture's objective is for regulated institutions to establish and maintain sound risk cultures that are aligned with their organizational goals, values, and risk appetite. A proper risk culture shall reduce the potential for undesirable behaviors that jeopardize institutions' financial wellbeing (APRA, 2016). If risk culture is embedded efficiently and effectively in an organization's business processes and practices, it can potentially add value to the business. Furthermore, it can enhance existing processes and ultimately help companies continue to manage and mitigate the existing and emerging risks that they continue to face in a changing world (Baxter \& Vermeulen, 2013).

Despite the strong need to integrate ERM and risk culture, their implementation in organizations remain fragmented. Risk practitioners are increasingly focused on designing and implementing risk management frameworks with less consideration to the initial establishment of sound risk culture. This study is undertaking to determine the relationship between risk culture and ERM empirically. The ERM and risk culture constructs are respectively measured from primary data using the Committee of Sponsoring Organization of the Treadway Commission (COSO) 2017 ERM framework and the UK IRM 2012 risk culture aspect model. These frameworks are well-grounded in theory and can do away with prior measurement methods of processing of text data and or the determination of designated risk persons in the organization. The measures provided can be used by risk practitioners to determine the level of risk management and the presence of risk culture in their organizations. Researchers can also use these measures in researches involving these constructs. The study is carried out with data from Africa that has been significantly left behind in ERM and risk culture studies. The findings shall, therefore, open up further studies within the region, and results shall expand studies on the broader world. The research uses partial least squares structural equation modeling (PLS-SEM) to promote its use in risk management studies. The next section details a review of the relevant literature and the development of hypotheses. The research design is then presented, followed by a presentation of data and results. Conclusions are then presented together with recommendations for future research.

\section{Literature Review and Research Hypotheses}

\subsection{Risk Culture and ERM}

There is little academic evidence as to why firms adopt ERM (Hoyt \& Liebenberg, 2015). Since the publication of the most popular ERM framework by COSO in 2004, research on evidence regarding the factors impacting ERM implementation has provided mixed results leading to the on-going debate on the ERM academic domain. Factors responsible for its implementation are both internal and external and have arisen from pressures from corporate governance bodies and institutional investors. The use of ERM systems in the rating methodologies also drives firms to adopt ERM. Shareholders' wealth maximization has also been cited as a reason for ERM adoption. Specific firm characteristics have been identified to be drivers for ERM implementation with mixed results. In all these studies, risk culture has failed to feature as a driver for ERM implementation.

Culture features prominently in COSO's (2017) definition of ERM and its first component of the framework, primarily due to the growing focus, attention, and importance of risk culture within ERM. Risk culture is believed to influence all aspects of ERM and possibly affects decision making. Klynveld Peat Marwick Goerdeler (KPMG) (2018) stated that risk culture is an integral part of ERM and that it is a crucial element in an organization's ERM framework as it can influence and, at the same time, is influenced by the other aspects of the ERM framework. Risk culture is thus a strong ERM pillar that binds all the elements of risk management and is vital in the effectiveness of risk management processes and practices. Research on the role of culture in the ERM domain is limited, warranting studies as to how organizational culture influences ERM adoption (Viscelli et al., 2016). An organization's risk culture can significantly impact on its capacity to take strategic risks and deliver on 
its stated performance (IRM, 2012). Risk culture is a fundamental tool for effective risk management, and that organizations that consider their culture understand the dynamics and efficiency of ERM practices better than those without (Ahmed \& Manab, 2016).

Selamat \& Ibrahim (2018) argued on the moderating effect of risk culture on the relationship between leadership and ERM implementation and concludes that risk culture moderates the relationship between leadership and ERM implementation without empirical evidence to support the hypothesis. Kimbrough \& Componation (2015) found support for the assumption of a positive association between organic cultures and levels of ERM implementation. Roslan \& Dahan (2013) argued that there is a significant relationship between risk culture and ERM and that risk culture also affects organizational performance. The organizational culture is critical in explaining its decision to adopt ERM and on the effectiveness of its implementation (Viscelli et al., 2016). Kleffner, Lee \& McGannon (2003), from a study of 19 members of the Canadian Risk and Insurance Society, concludes that organizational culture is the main deterrent on ERM implementation. Risk culture is the impact of corporate culture on risk management, so, if organizational culture significantly explains or deters ERM implementation, implicitly risk culture either positively or negatively impact ERM implementation. Consequently, the following hypothesis is stated:

Hypothesis 1: Risk culture is significantly associated with ERM adoption.

Prior researchers have put forward several firm characteristics that impact ERM implementation with mixed results. Control variables consistent with previous researchers are included to reduce the potential for confounding effects in the regression model.

\subsection{Control Variables}

\subsubsection{Firm Size}

Larger firms are more likely to implement an ERM program than smaller firms (Bohnert et al., 2018; Baxter, Bedard, Hoitash \& Yezegel, 2013; Pagach \& Warr, 2011; Hoyt \& Liebenberg, 2011). Larger firms have more resources to implement an ERM program whose implementation by itself is costly. Larger firms stand to benefit from economies of scale, government support, and greater access to capital markets. Larger firms are also more likely to suffer from principal-agency and information asymmetries problems. They also face a greater risk of financial distress and more volatile operating cash flows (Pagach \& Warr, 2011), making them more likely to adopt an ERM program. Other scholars have found contrary evidence that firm size has a significant and direct relationship with ERM implementation (Waweru \& Kisaka, 2013; Golshan \& Rasid, 2012). From the results of the mixed findings, the following hypothesis is stated:

Hypothesis 2: Larger Firms are more likely to implement ERM.

\subsubsection{Capital Opacity}

When firms have high intangible assets, they find it difficult to dispose of them at market value during financial distress and are most times under-valued. Firms with highly opaque assets are thus more likely to adopt and implement ERM to reduce information asymmetries (Pagach \& Warr, 2011). According to Hoyt \& Libenberg (2011), the decision to adopt an ERM is significantly related to the firm's capital opacity. However, Bohnert et al. (2018) did not establish Opacity as a statistically determinant factor for ERM implementation.

Hypothesis 3: Firms with higher opaque assets are more likely to implement ERM.

\subsubsection{Financial Leverage}

Financial leverage is the use of debt by a firm to pay out its liabilities, thereby exposing it to a higher risk of default. Financial risk is enhanced with greater financial leverage (Baxter et al., 2013). Firms that are optimistic about their risk management program may tend to increase their financial leverage since they are confident to face negative uncertainties (Bohnert et al., 2018; Hoyt \& Liebenberg, 2011). Greater leverage increases the chances of financial distress with the likelihood of implementing an ERM program (Pagach \& Warr, 2011). Bohnert et al. (2018), Hoyt \& Liebenberg (2011) empirically established a significant negative impact of leverage on ERM implementation. However, Golshan \& Rasid (2012) espoused that firms with higher financial leverage are more likely to have an ERM in place. According to Sax \& Anderson (2019), ERM is associated with lower financial leverage. From the various findings, the following hypothesis is put forward for investigation:

Hypothesis 4: Firms with a higher level of financial leverage are more likely to implement ERM.

\subsubsection{Financial Slack}

Hoyt \& Liebenberg (2011) indicated that firms that adopt ERM might increase financial slack to lower the 
probability of financial distress. Improved risk management practices may also lead firms to reduce the level of financial slack (Pagach \& Warr, 2010). Financial slack is not a significant determinant for ERM implementation (Bohnert et al., 2018). The researcher, therefore, hypothesizes that:

Hypothesis 5: Firms with higher financial slack are more likely to implement ERM.

\subsubsection{Board Composition}

Board independence is a function of its composition in terms of executive and non-executive directors. Boards of directors are now demanded to increase their risk oversight roles on the organizations they govern. Their level of independence is thus expected to be critical on the level of ERM implementation by management. The level of board independence has no significant relationship with ERM implementation (Waweru \& Kisaka, 2013; Golshan \& Rasid, 2012). Contrary to these findings, Beasley, Clune \& Hermanson (2005), Kleffner et al. (2003) studies concluded that the level of board independence has a significant impact on ERM implementation. This finding is because board independence is strongly associated with better corporate governance. From the results of the mixed findings, the following hypothesis is thus put forward for investigation:

Hypothesis 6: Board Composition is positively associated with ERM implementation.

\section{Research Design and Methods}

\subsection{Data Sources and Sample Selection}

The study focuses specifically on listed firms that have a greater public disclosure of ERM activities and are well regulated. An online survey questionnaire was administered to senior staff knowledgeable on the risk management practices of their organizations to obtain data for measurement of risk culture and ERM. Out of a total of 280 listed firms in Nigeria, Kenya, and Ghana as of December 2018 targeted, a total of 141 fully completed questionnaires were received and analyzed, giving a response rate of $50.4 \%$. The individual response rate per country is $55 \%, 44 \%$, and $54 \%$. The study sample is representative in terms of sectors and three different countries for the generalization of the findings of this research within Africa. Responses on risk culture and risk management practices were collected on a 5-point Likert scale ranging from strongly disagree (1) to strongly agree (5). Information on ERM practices was collected from 20 questions framed from the 20 principles of the COSO 2017 ERM framework and 33 questions using the UK IRM 2012 risk culture aspect model to solicit information on risk culture (Appendix).

The sample size of 141 exceeds minimum sample requirements of 97 using Cohen's (1992) power tables (effect size, $f^{2}=0.15$; the probability of error, $\alpha=0.05 ; 80 \%$ statistical power; highest number of independent variables of 6). An F-test on $G^{*}$ Power 3.1.9.7 $\left(f^{2}=0.15, \alpha=0.05\right.$, statistical power $=0.80$, six predictors, linear multiple regression fixed model, $\mathrm{R}^{2}$ deviation from zero) requires a sample size of 98 . Kock \& Hadaya (2018) 'inverse square root' and 'gamma-exponential' methods minimum sample size without prior information on the absolute minimum path coefficients is 160 and 146 respectively (Memon et al., 2020). A sample size of 141 is considered to be medium and adequate to detect the effects of interest.

\subsection{Variable Definition and Model Design}

\subsubsection{Dependent Variable}

The ERM construct is measured formatively by the five components of the framework, which are, in turn, measured reflectively by the 20 principles giving a reflective-formative model of the second-order (Fig. 1) with the measurement items as described in Appendix. The Pearson correlation between the five lower order constructs is significantly different from zero $(0.552<\mathrm{r}<0.923)$. A Confirmatory Tetrad Analysis - CTA PLS $(5,000$ subsamples, two-tailed, and $1 \%$ significance level) have zero straddled between most of the adjusted lower and upper confidence intervals. The test statistic is insignificant, and the null hypothesis (i.e., the tetrad equals zero and varnishes) is accepted. The reflective measurement mode of the model is confirmed (Gudergan, Ringle, Wende \& Will, 2008) and assessed according to indicator loadings, internal consistency reliability, convergent validity, and discriminant validity (Sarstedt, Hair, Cheah \& Becker, 2019; Hair, Risher, Sarstedt \& Ringle, 2019; Benitez, Henseler, Castillo \& Schuberth, 2019). Fig. 1 shows the full indicator loadings and constructs Average Variance Extracted (AVE) and path coefficients (path weighting scheme, maximum of 300 iterations, and stop criterion of $10^{-7}$ ). 


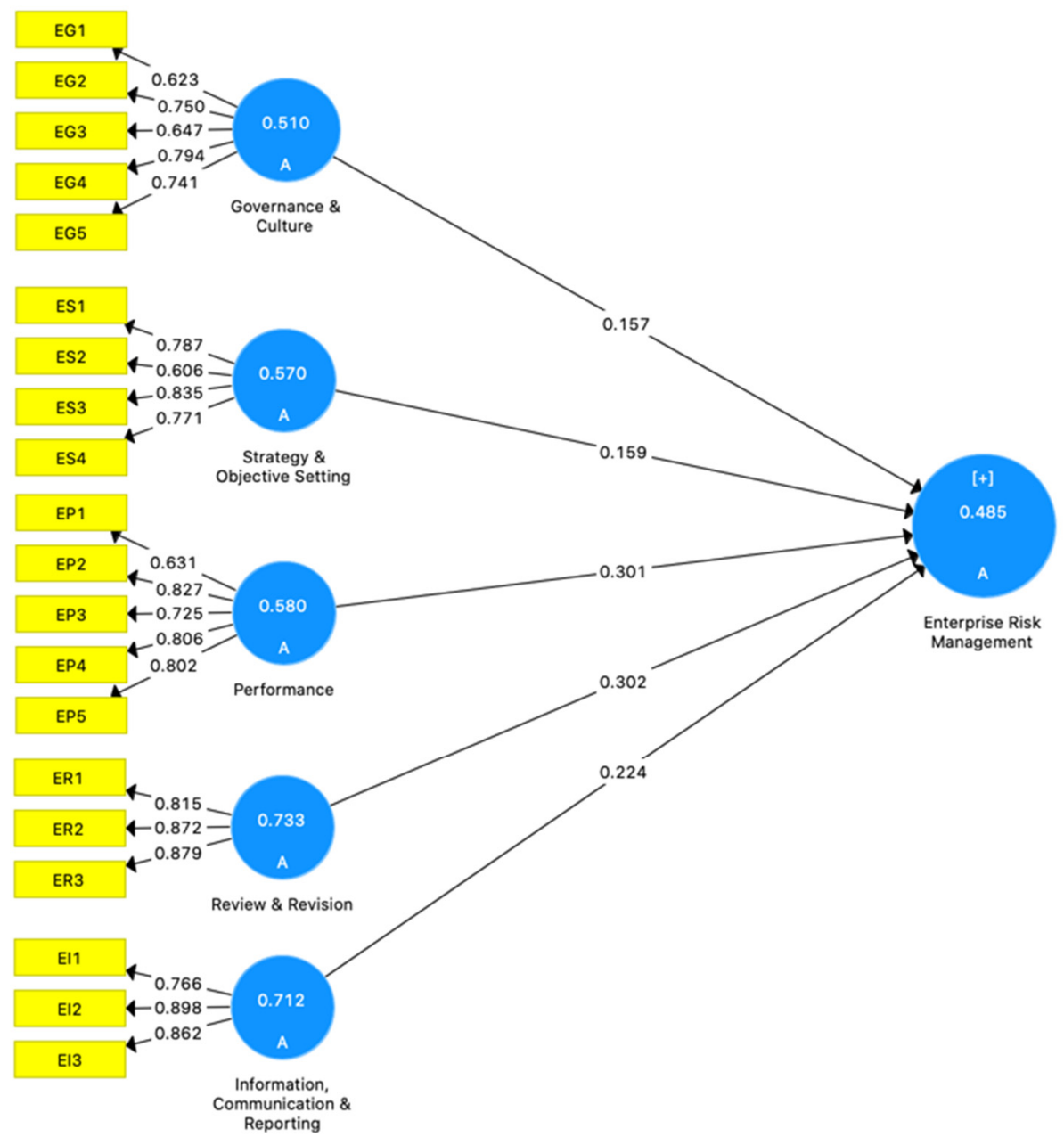

Figure 1. ERM measurement model

The four indicators, EP1 (Identification of Risks), ES2 (Defines Risk Appetite), EG1 (Exercise Board Risk Oversight), and EG3 (Definition of Desired Risk Culture), have loadings below 0.708. These indicators were deleted since their deletion increased the AVE of the latent variable they are theoretically connected to (Table 1), and at least three items still measure the constructs. These constructs have explained more than $50 \%$ of the indicator variance, with no other significant indicator omitted (Hair et al., 2019). 
Table 1. ERM and Risk Culture Constructs Reliability and Validity

\begin{tabular}{|c|c|c|c|c|c|c|}
\hline Construct & $\alpha$ & $\rho_{\mathrm{A}}$ & $\rho_{\mathrm{C}}$ & AVE & $2.5 \% \mathrm{CI}$ & $97.5 \% \mathrm{CI}$ \\
\hline Governance \& Culture & 0.742 & 0.740 & 0.854 & 0.661 & 0.819 & 0.883 \\
\hline Information, Communication \& Reporting & 0.796 & 0.806 & 0.881 & 0.712 & 0.846 & 0.911 \\
\hline Review \& Revision & 0.817 & 0.822 & 0.892 & 0.733 & 0.843 & 0.926 \\
\hline Strategy \& Objective Setting & 0.755 & 0.762 & 0.860 & 0.672 & 0.827 & 0.887 \\
\hline Accountability \& Governance & 0.867 & 0.873 & 0.904 & 0.654 & 0.873 & 0.928 \\
\hline Dealing with Bad News & 0.765 & 0.782 & 0.864 & 0.680 & 0.817 & 0.900 \\
\hline Decision Making & 0.890 & 0.910 & 0.910 & 0.592 & 0.882 & 0.934 \\
\hline Governance & 0.912 & 0.921 & 0.927 & 0.587 & 0.904 & 0.945 \\
\hline Informed Risk Decision & 0.802 & 0.804 & 0.883 & 0.716 & 0.842 & 0.916 \\
\hline Rewarding Appropriate Risk Taking & 0.807 & 0.808 & 0.874 & 0.634 & 0.832 & 0.907 \\
\hline Tone at the Top & 0.875 & 0.863 & 0.897 & 0.527 & 0.860 & 0.923 \\
\hline
\end{tabular}

Internal consistency reliability, as indicated by (Cronbach's Alpha $\alpha$, True Reliability $\rho_{\mathrm{A}}$, and Composite Reliability $\rho_{\mathrm{C}}$ ), have values between 0.700 and 0.950 thresholds (Table 1). The results are good, with no redundant items that can reduce the validity of the constructs (Hair et al., 2019; Henseler, Hubona \& Ray, 2016; Dijkstra and Henseler, 2015). Bootstrapping 5,000 samples, two tailed-test, 5\% significance level of composite reliability results (Table 1) have lower bound results above the 0.700 thresholds with all upper bound results below the 0.950 thresholds. The measurement scale is thus reliable and valid (Hair et al., 2019; Aguirre-Urreta \& Rönkkö, 2018). The AVE results of the five lower-order constructs before and after deletion of poorly loaded indicator variables are above the minimum threshold of 0.500 and hence acceptable (Hair et al., 2019; Henseler et al., 2016). The correlations between constructs are lower than the square root of the AVE for each construct, confirming the absence of discriminant validity issues (Fornell \& Larcker, 1981). Discriminant validity issues are also absent from an examination of cross-loadings as each measurement item correlates weakly with all other constructs except the one to which it is theoretically associated (Gefen and Straub, 2005; Chin, 1998). The results of Heterotrait-Monotrait (HTMT) ratio of correlations have two results (Review \& Revision -> Information, Communication and Reporting; Review \& Revision -> Performance) indicating discriminant validity problems using the $\mathrm{HTMT}_{0.90}$ threshold criterion (Table 2) (Franke and Starstedt, 2019; Henseler et al., 2016). 
Table 2. ERM and Risk Culture Constructs HTMT Results

\begin{tabular}{|c|c|c|c|}
\hline Path & Result & $\begin{array}{c}2.5 \% \\
\text { CI }\end{array}$ & $\begin{array}{c}97.5 \% \\
\text { CI }\end{array}$ \\
\hline Information, Communication \& Reporting -> Governance \& Culture & 0.71192 & 0.48975 & 0.90862 \\
\hline Performance -> Governance \& Culture & 0.69369 & 0.48073 & 0.87507 \\
\hline Performance -> Information, Communication \& Reporting & 0.85534 & 0.73709 & 0.95747 \\
\hline Review \& Revision -> Governance \& Culture & 0.76135 & 0.55394 & 0.95491 \\
\hline Review \& Revision -> Information, Communication \& Reporting & 0.94074 & 0.86545 & 1.01354 \\
\hline Review \& Revision -> Performance & 0.94309 & 0.81893 & 1.04445 \\
\hline Strategy \& Objective Setting -> Governance \& Culture & 0.60924 & 0.38037 & 0.84139 \\
\hline Strategy \& Objective Setting -> Information, Communication \& Reporting & 0.70526 & 0.53143 & 0.86497 \\
\hline Strategy \& Objective Setting -> Performance & 0.79989 & 0.60811 & 0.96116 \\
\hline Strategy \& Objective Setting -> Review \& Revision & 0.84260 & 0.66244 & 1.01069 \\
\hline Dealing with Bad News -> Accountability \& Governance & 0.86727 & 0.73636 & 0.97539 \\
\hline Informed Risk Decision -> Accountability \& Governance & 0.84388 & 0.73831 & 0.93163 \\
\hline Informed Risk Decision -> Dealing with Bad News & 0.76398 & 0.61771 & 0.89448 \\
\hline Rewarding Appropriate Risk Taking -> Accountability \& Governance & 0.94421 & 0.85506 & 1.02579 \\
\hline Rewarding Appropriate Risk Taking -> Dealing with Bad News & 0.92695 & 0.81626 & 1.02977 \\
\hline Rewarding Appropriate Risk Taking -> Informed Risk Decision & 0.99652 & 0.92287 & 1.07531 \\
\hline Risk Leadership -> Accountability \& Governance & 0.88419 & 0.75863 & 0.98121 \\
\hline Risk Leadership -> Dealing with Bad News & 0.90930 & 0.81630 & 1.00544 \\
\hline Risk Leadership -> Informed Risk Decision & 0.91091 & 0.81486 & 1.00485 \\
\hline Risk Leadership -> Rewarding Appropriate Risk Taking & 0.99634 & 0.92106 & 1.07394 \\
\hline Risk Resources -> Accountability \& Governance & 0.86472 & 0.78565 & 0.93611 \\
\hline Risk Resources -> Dealing with Bad News & 0.80506 & 0.68927 & 0.90066 \\
\hline Risk Resources -> Informed Risk Decision & 0.85632 & 0.74686 & 0.94918 \\
\hline Risk Resources -> Rewarding Appropriate Risk Taking & 0.95713 & 0.87994 & 1.02442 \\
\hline Risk Resources -> Risk Leadership & 0.93887 & 0.86126 & 1.00933 \\
\hline Risk Skills -> Accountability \& Governance & 0.72736 & 0.56425 & 0.86213 \\
\hline Risk Skills $->$ Dealing with Bad News & 0.82924 & 0.69391 & 0.95236 \\
\hline Risk Skills -> Informed Risk Decision & 0.72387 & 0.57662 & 0.84707 \\
\hline Risk Skills -> Rewarding Appropriate Risk Taking & 0.86640 & 0.74921 & 0.97240 \\
\hline Risk Skills -> Risk Leadership & 0.85700 & 0.73726 & 0.96180 \\
\hline Risk Skills -> Risk Resources & 0.87617 & 0.77278 & 0.95631 \\
\hline Risk Transparency -> Accountability \& Governance & 0.88797 & 0.80393 & 0.95503 \\
\hline Risk Transparency -> Dealing with Bad News & 0.92673 & 0.82304 & 1.02019 \\
\hline Risk Transparency -> Informed Risk Decision & 0.80324 & 0.65184 & 0.92054 \\
\hline Risk Transparency -> Rewarding Appropriate Risk Taking & 0.94983 & 0.86912 & 1.02569 \\
\hline Risk Transparency -> Risk Leadership & 0.91197 & 0.80171 & 1.01040 \\
\hline Risk Transparency -> Risk Resources & 0.88649 & 0.77826 & 0.96706 \\
\hline Risk Transparency -> Risk Skills & 0.89726 & 0.79249 & 0.98444 \\
\hline
\end{tabular}

These constructs are not empirically distinct and may be measuring the same thing to some respondents. The restriction of discriminant validity assessment in PLS-SEM through the comparison of a pair of constructs makes it problematic, needing future research to resolve (Franke \& Starstedt, 2019; Hamid, Sami \& Sidek, 2017). This criterion also has high sensitivity and specificity in detecting discriminant validity problems.

16 of the 20 measurement items are validated using the indicators loading, internal consistency, convergent, and discriminant validity. The second-order model was reduced to a first-order model by saving the latent variable scores of the five lower-order constructs in the first stage as a new dataset in line with the embedded two-stage approach. The first-order model becomes parsimonious with ERM measured by five multi-items with the five lower-order constructs respectively measured as single items that capture each construct latent variable scores from the previous stage.

\subsubsection{Independent Variable}

The measurement specification of the lower-order constructs is confirmed reflective and hence assessed using 
Indicator Loadings, Internal Consistency, Convergent Validity, and Discriminant Validity. The full indicator loadings are shown in Fig. 2 with the constructs AVE and path coefficients. The three indicator variables RTR1 (Distinct Tone at the Top), RCS2 (Visible Internal Controls) \& RCS4 (Encouragement \& Development of Risk Skills) have loadings below 0.708 and were therefore considered for deletion. The AVE of the "Risk Skills" latent variable is 0.606 without the deletion of these two measurement indicators. The latent variable "Competence" to which this latent variable is connected to also has its AVE as 0.581. The omission of these two measurement indicators will leave the latent variable with two measurement indicators. The theory will thus suggest their retention since the AVE is already above the 0.50 threshold. RCS4 with lower loading of 0.636 was deleted while RCS2 was retained to have at least three indicators measuring the latent variable. RTR1 connected to the Risk Leadership construct was deleted to leave four measurement indicators for this construct. Doing so resulted in an increase of AVE of the latent variable "Risk Leadership" from 0.580 to 0.595 and "Risk Skills" from 0.606 to 0.720 and was therefore permanently deleted (Table 1) (Hair et al., 2019).

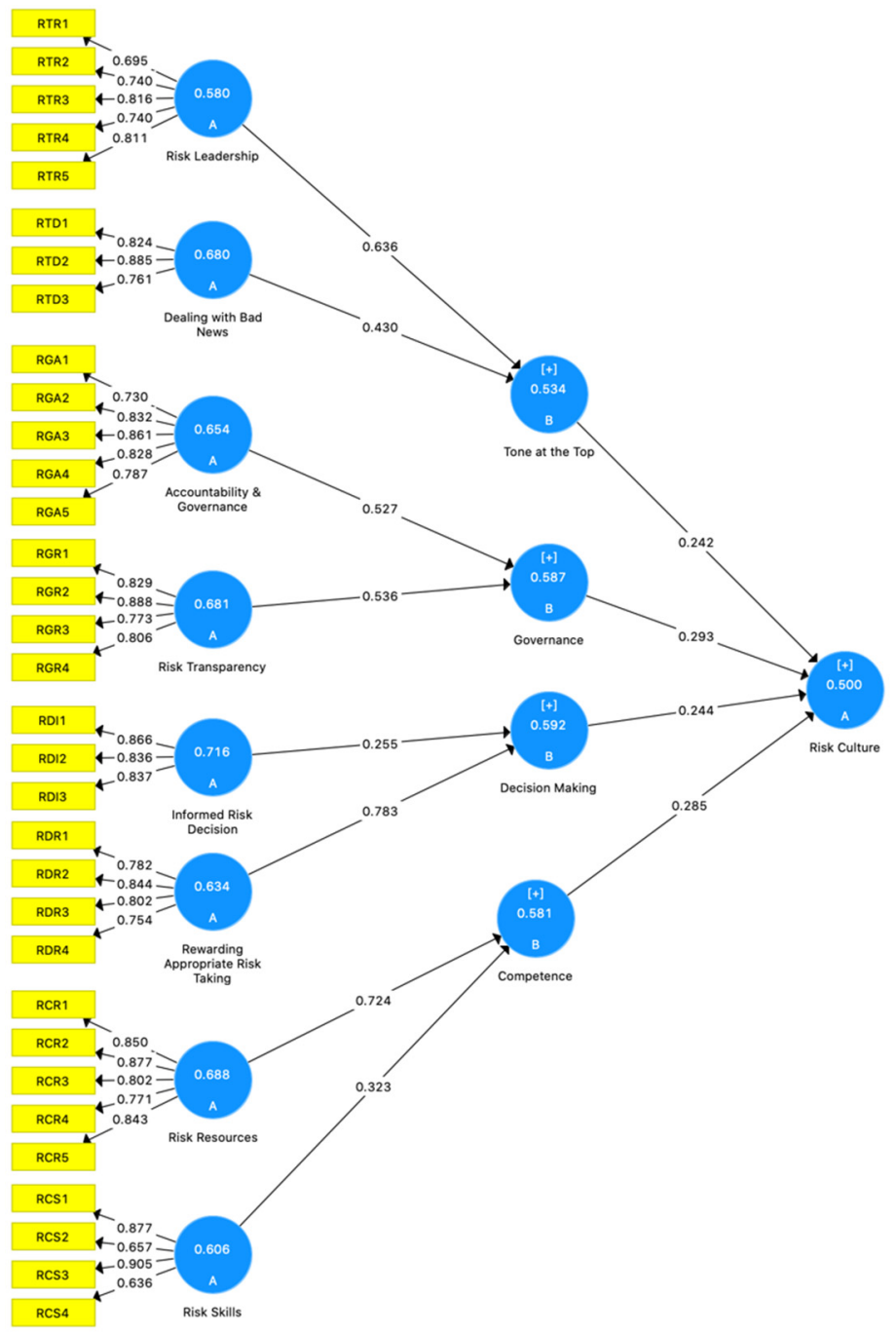

Figure 2. Risk culture measurement model

The results of all three measures of construct reliability (Table 1) are above 0.700 and below 0.950 thresholds meaning that the results are good and acceptable (Hair et al., 2019; Henseler et al., 2016; Dijkstra \& Henseler, 2015). The results of bootstrap confidence intervals (5,000 samples, two tailed-test, $5 \%$ significance level) have results of composite reliability lower bound significantly above the 0.700 thresholds with all upper bound results (except Risk Leadership) below the 0.950 thresholds (Table 1). These results also confirm the measurement scale as reliable and valid (Hair et al., 2019; Aguirre-Urreta \& Rönkkö, 2018). The AVE for all first and second-order constructs in the measurement model (Table1) is above the 0.50 threshold, indicating that there are no 
convergent validity issues (Hair et al., 2019; Henseler et al., 2016).

The square root of the AVE for each first-order latent variable is greater than the correlation involving the constructs except "Rewarding Appropriate Risk-taking with "Risk Leadership" and "Risk Resources," which are marginally higher. These three first-order constructs are not empirically distinct in the model and may measure the same thing to some respondents. The results of the cross-loadings results, except RCS2 connected to the latent variable "Risk Skills," indicates that each measurement item correlates weakly with all other constructs except the one to which it is theoretically connected, thereby confirming that the measures are discriminant valid (Gefen \& Straub, 2005; Chin, 1998). RCS2 has an outer loading less than 0.708 (i.e., 0.687) but was retained to have a minimum of three measurement indicators to the construct as required. Using Henseler Ringle \& Sarstedt's (2015) HTMT method for discriminant validity, eleven of twenty-eight results exceeded the threshold of 0.900 . This is possibly due to the conceptually very similar constructs in the model, which is typical in higher-order models (Teo, Su Luan \& Sing, 2008). The results for which HTMT $\geq 1$ have nine items slightly exceeding the 1.000 thresholds. It is reasonable to accept that discriminant validity issues between constructs are not very critical (Hair, Hult, Ringle \& Sarstedt, 2017).

The latent variable scores of the four second-order constructs in the model are saved and added as new variables to the data set in line with the embedded two-stage approach. The model is thus parsimonious, and the higher-order model is avoided in further analysis, as advised by methodological researchers. Risk Culture is measured in further analysis with four multiple items as required for abstract concepts (Diamantopolous, Sarstedt, Fuchs, Wilczynski \& Kaiser, 2012; Hayduk \& Littvay, 2012). Such a risk culture measurement is superior to "Text Analysis" used to measure risk culture in prior studies (Carretta, Farina \& Schwizer, 2017).

\subsubsection{Control Variables}

The study control variables are as indicated in Table 3, with their measurement methods together with references from the literature.

Table 3. Control Variables Measurement

\begin{tabular}{|c|c|c|c|}
\hline Variable & Abbreviation & Measurement & Citations \\
\hline Firm Size & SIZE & $\begin{array}{l}\text { Natural logarithm of the } \\
\text { book value of Assets }\end{array}$ & $\begin{array}{l}\text { Anton, 2018; } \\
\text { Bohnert et al. (2018); } \\
\text { Lechner \& Gatzert (2017); } \\
\text { Wang et al. (2017) }\end{array}$ \\
\hline Capital Opacity & CAOP & $\begin{array}{l}\text { Intangible assets / Book } \\
\text { value of Assets }\end{array}$ & $\begin{array}{l}\text { Bohnert et al. (2018); } \\
\text { Lechner \& Gatzert (2017); } \\
\text { Ghazali \& Manab (2013); } \\
\text { Golshan \& Rasid (2012) }\end{array}$ \\
\hline Financial Leverage & LEVG & $\begin{array}{l}\text { Book value of Liabilities / } \\
\text { Book value of Assets }\end{array}$ & $\begin{array}{l}\text { Wang et al. (2017) } \\
\text { Ghazali \& Manab (2013); } \\
\text { Manab \& Ghazali (2013); } \\
\text { Golshan \& Rasid }(2012) \text {; } \\
\text { Pagach \& Warr }(2007,2010)\end{array}$ \\
\hline Financial Slack & FSLK & $\begin{array}{l}\text { Cash and short-term } \\
\text { investments / Book value of } \\
\text { assets }\end{array}$ & $\begin{array}{l}\text { Bohnert et al. (2018); } \\
\text { Ghazali \& Manab (2013) }\end{array}$ \\
\hline Board Independence & $\mathrm{BDCO}$ & $\begin{array}{l}\text { Number of non-executive } \\
\text { members of the board / total } \\
\text { number of BOD } * 100\end{array}$ & $\begin{array}{l}\text { Waweru \& Kisaka (2013); } \\
\text { Golshan \& Rasid (2012) }\end{array}$ \\
\hline
\end{tabular}

\subsubsection{Model Specification}

From the various hypotheses developed, the following mathematically equation is put forward for empirical analysis:

$$
\mathrm{ERM}_{\mathrm{i}}=\beta_{0 \mathrm{i}}+\beta_{1 \mathrm{i}} \mathrm{RISC}_{\mathrm{i}}+\beta_{2 \mathrm{i}} \mathrm{SIZE}_{\mathrm{i}}+\beta_{3 \mathrm{i}} \mathrm{CAOP}_{\mathrm{i}}+\mathrm{B}_{4 \mathrm{i}} \mathrm{LEVG}_{\mathrm{i}}+\beta_{5 \mathrm{i}} \mathrm{FSLK}_{\mathrm{i}}+\beta_{6 \mathrm{i}} \mathrm{BDCO}_{\mathrm{i}}+\varepsilon_{\mathrm{i}}
$$

Where:

$E R M_{i}$ is the dependent variable, ERM, for firm $i$.

$\beta_{0 \mathrm{i}}$ is the constant term for firm $\mathrm{i}$.

$\beta_{1 \mathrm{i}}$ to $\beta_{6 \mathrm{i}}$ are the coefficients of firm i relating the 6 explanatory variables to the dependent variable. 
$\varepsilon_{\mathrm{i}}$ is the error term for firm i.

The independent variable (risk culture) and dependent variable (ERM) are latent variables with multiple indicators making the use of SEM advantageous to ordinary multiple linear regression modeling (Gefen, Rigdon \& Straub, 2011). PLS-SEM has become a standard and prevalent tool in business and social science research where multivariate statistical methods are employed in analyzing complex inter-relationships between observed and latent variables (Hair et al., 2019; Sarstedt et al., 2019; Aguirre-Urreta \& Rönkkö, 2018). The path coefficients can be obtained, and the null hypotheses tested by PLS-SEM with bootstrapping (Henseler et al., 2015). The method is used in studies with relatively small sample sizes, in capturing sub-dimension of constructs, data obtained from secondary sources, use of financial ratios, non-normality of data, and in testing a theoretical framework from a prediction perspective (Hair et al., 2019; Benitez et al., 2019; Gefen et al. 2011), hence the choice of PLS-SEM in this study.

\subsection{Descriptive Statistics}

Table 4 shows the demographic characteristics of respondents with the various sectors of study firms presented in Table 5. Graduates and postgraduates' respondents respectively represent $96.4 \%$ and $65.2 \%$. $79.4 \%$ of respondents are members of professional bodies such as accounting and risk management. In terms of experience, $60.2 \%$ have more than ten years, with $12.8 \%$ having less than five years of experience. $53.9 \%$ of respondents are at senior or directorate level in their organizations who report directly to the board of directors. It is reasonable to assume that the respondents have the requisite professional education, experience, and responsibility levels within their organization to report on their risk management practices.

\begin{tabular}{llcc} 
Table 4. Demographic Statistics of Respondents & & \\
\hline Category & Sub Category & Frequency & Percentage \\
\hline Gender & Male & 126 & $89.4 \%$ \\
Education & Female & 15 & $10.6 \%$ \\
& Postgraduate & 92 & $65.2 \%$ \\
Professional Membership & Graduate & 44 & $31.2 \%$ \\
& Other(s) & 5 & $3.5 \%$ \\
Main Job Position & Yes & 112 & $79.4 \%$ \\
& No & 29 & $20.6 \%$ \\
& Director & 18 & $12.8 \%$ \\
& Senior Management & 58 & $41.1 \%$ \\
Years at Position & Middle Management & 43 & $30.5 \%$ \\
& Junior Management & 16 & $11.3 \%$ \\
& Other(s) & 6 & $4.3 \%$ \\
& less than 5 years & 74 & $52.5 \%$ \\
& $6-10$ years & 56 & $39.7 \%$ \\
Years in Organization & $11-15$ years & 4 & $2.8 \%$ \\
& $16-20$ years & 3 & $2.1 \%$ \\
& more than 20 years & 4 & $2.8 \%$ \\
& less than 5 years & 76 & $53.9 \%$ \\
& $6-10$ years & 38 & $27.0 \%$ \\
& $11-15$ years & 19 & $13.5 \%$ \\
& $16-20$ years & 3 & $2.1 \%$ \\
& more than 20 years & 5 & $3.5 \%$ \\
& less than 5 years & 18 & $12.8 \%$ \\
& $6-10$ years & 38 & $27.0 \%$ \\
& $11-15$ years & 43 & $30.5 \%$ \\
& $16-20$ years & 13 & $9.2 \%$ \\
& more than 20 years & 29 & $20.6 \%$ \\
\hline
\end{tabular}

Sample Total (N)

141

The banking sector is mostly represented (22.7\%), followed by the insurance industry (15.6\%). The least sector represented is mining and exploration $(1.4 \%)$ and construction \& allied $(2.8 \%)$. The study firms are drawn from 10 different sectors of the economy, providing a perfect representative sample. The influence of the financial service industry in terms of risk regulation does not impact the study results strongly as the other sectors represent $61.7 \%$. 
Table 5. Samples per Sector

\begin{tabular}{lccc}
\hline Sector & Frequency & Percentage & Cumulative \\
\hline Agriculture & 6 & $4.3 \%$ & $4.3 \%$ \\
Banking & 32 & $22.7 \%$ & $27.0 \%$ \\
Commercial \& Services & 27 & $19.1 \%$ & $46.1 \%$ \\
Construction \& Allied & 4 & $2.8 \%$ & $48.9 \%$ \\
Energy \& Petroleum & 10 & $7.1 \%$ & $56.0 \%$ \\
Insurance & 22 & $15.6 \%$ & $71.6 \%$ \\
Real Estate \& Investment & 5 & $3.5 \%$ & $75.2 \%$ \\
Manufacturing \& Allied & 27 & $19.1 \%$ & $94.3 \%$ \\
Mining \& Exploration & 2 & $1.4 \%$ & $95.7 \%$ \\
Telecommunication \& Technology & 6 & $4.3 \%$ & $100.0 \%$ \\
\hline Sample Total $(\mathbf{N})$ & $\mathbf{1 4 1}$ & &
\end{tabular}

The variables firm size, capital opacity, and board composition have results of skewness and kurtosis lying between -1 and +1 are therefore not highly skewed and peaked (Hair et al., 2017). The other variables' financial leverage and financial slack have peaked, and skewed distribution as the results exceeded the limits of -1 and +1 . Non-normality is confirmed from the results of Kolmogorov-Smirnov (K-S) and Shapiro-Wilk (S-W) tests (Table 6), especially the latter that is more specific and powerful in the case of small sample size (Ryan, 2020). The significance of each of the K-S and S-W test results are shown in parentheses. The K-S and S-W test results for firm size are insignificant, indicating that the data for this variable follows a normal distribution. This is so because firm size is calculated as the natural logarithm of the book value of assets. Data for all other variables is asymmetric and can be handled by the non-parametric method of PLS-SEM.

Table 6. Descriptive Statistics of Secondary Data
\begin{tabular}{lcccccccc}
\hline Variable & Min. & Max. & Mean & Std. Dev. & Skewness & Kurtosis & K-S & S-W \\
\hline Firm Size & 13.048 & 23.886 & 18.477 & 2.336 & 0.222 & $(0.595)$ & $0.065(0.200)$ & $0.983(0.075)$ \\
Financial Leverage & 0.022 & 2.852 & 0.566 & 0.331 & 2.207 & 14.694 & $0.106(0.001)$ & $0.833(0.000)$ \\
Capital Opacity & 0.099 & 99.837 & 63.496 & 30.438 & $(0.327)$ & $(1.284)$ & $0.151(0.000)$ & $0.900(0.000)$ \\
Financial Slack & 0.004 & 53.224 & 11.125 & 11.323 & 1.358 & 1.270 & $0.204(0.000)$ & $0.833(0.000)$ \\
Board Composition & 50.000 & 100.000 & 77.388 & 11.128 & $(0.599)$ & $(0.513)$ & $0.160(0.000)$ & $0.942(0.000)$ \\
\hline
\end{tabular}

Sample Total

141

\section{Empirical Results}

\subsection{Regression Results}

The regression results are obtained from a 5,000 bootstraps sample, $\mathrm{BCa}$, one-tailed, 5\% significance level, and are as shown in Fig. 3 and Table 7.

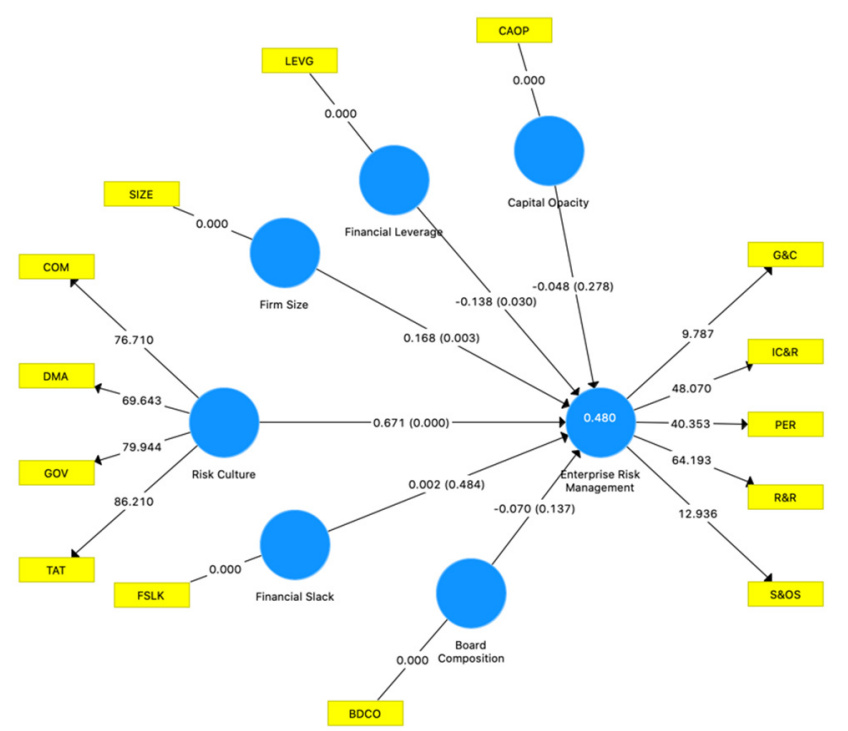

Figure 3. Structural model 
Table 7. Model Path Coefficients

\begin{tabular}{lccccc}
\hline Path & Coefficient & P Values & T Values & $\mathbf{5 . 0 \%}$ CI & $\mathbf{9 5 \%}$ CI \\
\hline Board Composition -> ERM & -0.070 & 0.137 & 1.095 & -0.173 & 0.041 \\
Capital Opacity -> ERM & -0.048 & 0.278 & 0.589 & -0.181 & 0.085 \\
Financial Leverage -> ERM & -0.138 & 0.030 & 1.875 & -0.260 & -0.016 \\
Financial Slack -> ERM & 0.002 & 0.484 & 0.041 & -0.103 & 0.098 \\
Firm Size -> ERM & 0.168 & 0.003 & 2.718 & 0.067 & 0.270 \\
Risk Culture -> ERM & 0.671 & 0.000 & 11.980 & 0.575 & 0.757 \\
\hline $\mathbf{5 , 0 0 0}$ bre
\end{tabular}

5,000 bootsrap samples, BCa, one-tailed, $5 \%$

Significant and robust path coefficients for risk culture, firm Size, and financial leverage with ERM were reported using both the $\mathrm{p}$-value criterion $(\mathrm{p}<0.05)$, $\mathrm{t}$-value $(\mathrm{t}>1.960)$, and the $95 \% \mathrm{BCa}$ confidence intervals.

\subsection{Discussion of Empirical Results}

\section{H1: Risk culture is significantly associated with ERM adoption.}

The path coefficient between risk culture and ERM is 0.671 and significant at the $5.0 \%$ level $(\beta=0.671, p<$ 0.005). This result supports the hypothesized relationship that the two constructs have a significant positive relationship. This finding confirms the proposition of KPMG (2018) that risk culture influences and is influenced by ERM. The findings are also consistent with prior researchers who opined the effect of culture on ERM implementation (Viscelli et al., 2016; Kimbrough \& Componation, 2009; Kleffner et al., 2003). The empirical results provide evidence to Roslan \& Dahan (2013) argument that risk culture and ERM has a significant positive relationship. When a sound risk culture exists in an organization, risk issues are discussed and escalated at all levels within the organization. Everybody in the organization takes responsibility and account for his/her actions. Employees can easily embrace any risk management program and will not see ERM as a compliant issue. ERM implementation can thus flourish in organizations with sound risk culture.

\section{H2: Larger Firms are more likely to implement ERM.}

This hypothesis is supported by this study $(\beta=0.168, \mathrm{p}=0.003)$. The revealed relationship is significant at a $5 \%$ significance level, and the strength of the relationship is relatively strong and positive, i.e., larger firms are more likely to implement an ERM program. This finding finds support to those of Bohnert et al. (2018); Baxter et al. (2013); Pagach \& Warr (2011); Hoyt \& Liebenberg (2011), who found out that larger firms are more likely to adopt ERM than smaller firms. However, the results are contrary to those of Waweru \& Kisaka (2013); Golshan \& Rasid (2012), who failed to find a significant and direct relationship between firm size and ERM implementation. Larger firms have a lot of resources at their disposal that can be used to implement an ERM program. They suffer from information asymmetries because of their size, requiring them to implement an ERM program to obtain information on all risks the organization faces at all levels. Hence, increasing scope and complexity of risks, as well as a greater risk of financial distress of larger companies, lead to more high-quality risk management implementations.

\section{H3: Firms with higher opaque assets are more likely to implement ERM.}

The decision to adopt an ERM is found to have an insignificant relationship with ERM adoption $(\beta=-0.048, p=$ 0.278). This finding does not support those of Pagach \& Warr (2011); Hoyt \& Liebenberg (2011) but consistent with the results of Bohnert et al. (2018), who did not establish Opacity as a statistically determinant factor for ERM implementation. The study establishes that firms with higher opaque assets are less likely to adopt an ERM program. The finding contradicts the assumption that such firms have a higher likelihood of implementing an ERM to provide public information about their risk management practices in order to dispose of their assets at fair market value when in financial distress. Due to the "principal-agency" conflict, they may fail to do so as self-seeking managers take actions in their best interest against the interest of the organizations they govern.

\section{H4: Firms with a higher level of financial leverage are more likely to implement ERM.}

The relationship between financial leverage and ERM adoption revealed is negative and significant. The hypothesis is accepted at the $5 \%$ level $(\beta=-0.138, \mathrm{p}=0.030)$. This result fails to support the findings of Golshan \& Rasid (2012), Pagach \& Warr (2011), who found a higher likelihood of ERM adoption by highly financially levered firms. However, support is provided by this study for the findings of Sax \& Andersen (2019), Bohnert et al. (2018), Hoyt \& Liebenberg (2011), who empirically established a significant negative impact of financial 
leverage on ERM implementation. The results support the argument that firms with higher ERM quality may reduce leverage to decrease the risk of debt payout defaults.

\section{H5: Firms with higher financial slack are more likely to implement ERM.}

A direct and insignificant relationship between financial slack and ERM adoption was established $(\beta=0.002, p=$ 0.484). The study did not support the findings of Pagach \& Warr (2010), who established a significant indirect relationship, and Hoyt \& Liebenberg's (2011) findings that ERM adoption is matched with an increase in financial slack to lower the probability of financial distress. This study supports Bohnert et al. (2018) findings that the decision to adopt ERM is not dependent on the level of a firm financial slack. Firms are expected to use available cash to fund net-present value projects for the continued increase in firm value. Such firms with very high disposable cash are in a position to implement an ERM program. "Principal-agency" theory requires management to hold on to a high amount of cash to use for their self-benefits rather than that of the organization.

\section{H6: Board Composition is positively associated with ERM implementation.}

The relationship between board composition and ERM adoption is insignificant $(\beta=-0.070, p=0.137)$. This finding supports the studies of Waweru \& Kisaka (2013), Golshan \& Rasid (2012). It contradicts those of Beasley et al. (2005) and Kleffner et al. (2003) studies that concluded that the level of board independence has a significant impact on ERM implementation. Corporate governance requires organizations to have more non-executive directors on their boards. It does become a complaint issue for organizations and does not guaranty risk oversight as required.

\subsection{Robust Test}

\subsubsection{Common Method Bias}

Data for ERM and risk culture were gathered from a single source with the possibility of creating common method bias. Procedurally, this was handled by assuring respondent anonymity, the presence of no right or wrong answer, and the option to skip or omit any question that is not comfortable to the respondent. Statistically, a full collinearity assessment at factor level with ERM serving as the dependent variable has an inner VIF value of 1.047, which is less than 3.3, confirming that the model is free from common method bias (Kock, 2015).

\subsubsection{Model Fit}

The model standard root mean residual (SRMR) is less than 0.080, indicating a good model fit (Henseler \& Sarstedt, 2013; Hu \& Bentler, 1999). Original values of the geodesic distance (d_G) fall below the upper bound of the $95 \%$ confidence interval with the squared Euclidean distance (d_ULs) slightly above the upper bound of the 99\% confidence interval indicating that the model has a "satisfactory to good fit" (Dijkstra \& Henseler, 2015; Henseler et al., 2013).

Table 8. Model Measures of Fit

\begin{tabular}{llll}
\hline Discrepancy & Value & HI $_{95}$ & HI $_{99}$ \\
\hline SRMR (Estimated) & 0.049 & 0.044 & 0.049 \\
d_ULS $($ Estimated) & 0.250 & 0.204 & 0.248 \\
d_G (Estimated) & 0.126 & 0.182 & 0.203 \\
\hline
\end{tabular}

Note. 5,000 bootstrap samples, $\mathrm{BCa}$, one-tailed, $\alpha=5 \%$

\subsubsection{Model Predictive Capability}

The coefficient of determination $\left(\mathrm{R}^{2}\right)$ for the ERM construct with all control variables included is $0.480(\mathrm{p}<0.05)$ (Table 9). With the removal of all control variables, the $\mathrm{R}^{2}$ value is $0.449(\mathrm{p}<0.05)$. The $\mathrm{R}^{2}$ effect size is calculated as 0.06 , and this is considered as small (Cohen, 1988). The improvement of $\mathrm{R}^{2}$ by $6.5 \%$ justifies the inclusion of control variables in the model. The $\mathrm{R}^{2}$ value is above 0.33 and almost 0.50 and can be considered as moderate (Hair, Hult, Ringle \& Sarstedt, 2017; Chin, 1988). The "cross-validated redundancy approach" results for the out-of-sample predictive relevance using the blindfolding procedure gives a $\mathrm{Q}^{2}$ value more than zero, indicating predictive relevance (Geisser, 1974; Stone, 1974). The $\mathrm{Q}^{2}$ is more than 0.250 , which is considered as a medium with a small effect size $\mathrm{q}^{2}$ of 0.035 (Hair et al., 2019, 2017). 
Table 9. Model predicted results

\begin{tabular}{llllll}
\hline & $\mathbf{R}^{\mathbf{2}}$ & Adjusted R & SSO & SSE & Q $^{\mathbf{2}}$ (1-SSE/SSO) \\
\hline Scenario A & 0.480 & 0.457 & 705.000 & 482.272 & 0.316 \\
Scenario B & 0.449 & 0.445 & 705.000 & 495.366 & 0.297 \\
\hline
\end{tabular}

Note. Scenario A (All six variables as predictors) and Scenario B (Risk Culture only as a predictor).

\section{Research Conclusion}

The study has empirically established a significant positive relationship between risk culture and ERM of publicly listed firms in three stock exchanges in Africa. It has extended previous academic works on determinants of ERM implementation and found support for firm size and financial leverage as significant determinants for ERM implementation. Other firm characteristics like capital opacity, board independence, and financial slack do not significantly influence the decision to adopt ERM. Risk culture is one of the constructs that are not easily quantified, creating challenges in its measurement and management. The study has confirmed the UK IRM 2012 risk culture aspect model as useful in promoting a risk-aware culture and embedding risk-related measures into performance management. The measure shall help organizations to understand and monitor their own evolving risk culture.

The relatively small sample size in this study may influence the extent to which these findings may be generalized to other emerging markets. Also, firms have been studies across industries with the potential to weaken the direct effects of the studied variables on ERM implementation. Some of the independent and dependent variables' measures are derived from executive respondents that may be influenced by subjective biases. Though this was circumvented by including more objective measures of ERM and risk culture, the researcher cannot be fully confident that such biases did not exist. ERM and risk culture were measured by well-established frameworks, and how the firm's leadership and employees implemented these frameworks were not taken into consideration. Notwithstanding these limitations, the responses obtained provides a rich opportunity to explore the extent to which risk culture and ERM are empirically related. Future research in this direction should be carried out with a larger sample size from other emerging economies that could bring new contributions to the growing empirical research on risk culture and ERM.

\section{References}

Abdullah, M. H. S. B., Janor, H., Hamid, M. A., \& Yatim, P. (2017). The Effect of Enterprise Risk Management on Firm Value: Evidence from Malaysian Technology Firms. Jurnal Pengurusan, 49(15). https://doi.org/10.17576/pengurusan-2017-49-01

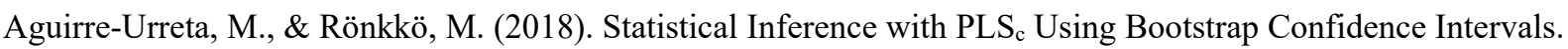
MIS Quarterly, 42(3), 1001-1020. https://doi.org/10.25300/MISQ/2018/13587

Agustina, L., \& Baroroh, N. (2016). The Relationship Between Enterprise Risk Management (ERM) And Firm Value Mediated through the Financial Performance. Review of Integrative Business and Economics Research, 5(1), 128-138. https://buscompress.com/journal-home.html

Ahmed, I., \& Manab, N. A. (2016). Moderating Role of Board Equity Ownership on the Relationship between Enterprise Risk Management Implementation and Firms Performance: A Proposed Model. International Journal of Management Research and Review, 6(1), 21-30.

Alawattegama, K. K. (2018). The Impact of Enterprise Risk Management on Firm Performance: Evidence from Sri Lankan Banking and Finance Industry. International Journal of Business and Management, 13(1), 225-237. https://doi.org/10.5296/jmr.v10i1.12429

Aleisa, Y. (2018). Factors Affecting Implementation of Enterprise Risk Management: An Exploratory Study among Saudi Organizations. Journal of Economics, Business and Management, 6(1), 1-12. https://doi.org/10.18178/joebm.2018.6.1.543

Anton, S. G. (2018). The Impact of Enterprise Risk Management on Firm Value: Empirical Evidence from Romanian Non-Financial Firms. Engineering Economics, 29(2), 151-157. https://dx.doi.org/10.5755/j01.ee.29.2.16426

Ashby, S., Power, M., \& Palermo, T. (2014). A Brave New World? Making Sense of Practitioner and Regulator Perspectives on Risk Culture. Journal of Financial Perspectives, 2(3). https://ssrn.com/abstract=3079614

Australian Prudential Regulation Authority. (2016). Risk Culture. Information Paper. Retrieved from 
https://www.apra.gov.au/sites/default/files/161018-information-paper-risk-culture1.pdf

Baxter, D., \& Vermeulen, P. (2013). Intelligent ERM: Evolving Risk Management. Journal of Financial Perspectives, 1(3). https://ssrn.com/abstract=3077939

Baxter, R., Bedard, J. C., Hoitash, R., \& Yezegel, A. (2013). Enterprise Risk Management Program Quality: Determinants, Value Relevance, and the Financial Crisis. Contemporary Accounting Research, 30(4), 1264-1295. https://doi.org/10.1111/j.1911-3846.2012.01194.x

Beasley, M., Branson, B., \& Pagach, D. (2015). An Analysis of the Maturity and Strategic Impact of Investments in ERM. Journal of Accounting and Public Policy, 34(3), 219-243. https://doi.org/10.1016/j.jaccpubpol.2015.01.001

Beasley, M., Clune, R., \& Hermanson, R. (2005). Enterprise Risk Management: An Empirical Analysis of Factors Associated with the Extent of Implementation. Journal of Accounting \& Public Policy, 24(6), 521-531. https://doi.org/10.1016/j.jaccpubpol.2005.10.001

Becker, J. M., Klein, K., \& Wetzels, M. (2012). Hierarchical Latent Variable Models in PLS-SEM: Guidelines for Using Reflective-Formative Type Models. Long Range Planning, 45, 359-394. https://doi.org/10.1016/j.lrp.201210.001

Becker, J. M., Ringle, C. M., Sarstedt, M., \& Völckner, F. (2015). How Collinearity Affect Mixture Regression Results. Marketing Letters, 26(4), 643-659. https://doi.org/10.1007/s11002-014-9299-9

Benitez, J., Henseler, J., Castillo, A., \& Schuberth, F. (2019). How to Perform and Report an Impactful Analysis Using Partial Least Squares: Guidelines for Confirmatory and Exploratory IS Research. https://doi.org/10.1016/j.im.2019.05.003

Bohnert, A., Gatzert, N., Hoyt, R. E., \& Lechner, P. (2018). The Drivers and Value of Enterprise Risk Management: Evidence from ERM Ratings. The European Journal of Finance, 25(3), 234-255. https://doi.org/10.1080/1351847X.2018.1514314

Bott, J., \& Milkau, U. (2018). Risk Culture and the Role Model of the Honorable Merchant. Journal of Risk and Financial Management, 11(40), 11. https://doi.org/10.3390/jrmf11030040

Bromiley, P., Mcshane, M., Nair, A., \& Rustambekov, E. (2015). Enterprise Risk Management: Review, Critique, and Research Directions. Long Range Planning, 48, 265-276. https://doi.org/10.1016/j.lrp.2014.07.005

Carretta, A., Farina, V., \& Schwizer, P. (2017). Risk Culture and Banking Supervision. Journal of Financial Regulation and Compliance, 209-226. https://EconPapers.repec.org/RePEc:eme:jfrcpp:jfrc-03-2016-0019

Chin, W. W. (1998). The partial least squares approach to structural equation modeling. Modern Methods for Business Research, 95(2), 29-336.

Cohen, J. (1988). Statistical Power Analysis for the Behavioral Sciences: Lawrence Erlbaum Associates.

Cohen, J. (1992). A Power Primer. Quantitative Methods in Psychology, 112(1), 155-159. https://doi.org/10.1037/0033-2909.112.1.155

Committee of Sponsoring Organizations of Treadway Commission (COSO). (2017). Enterprise Risk Management - Integrating with Strategy and Performance. Association of International Certified Professional Accountants.

Committee of Sponsoring Organizations of Treadway Commission (COSO). (2004). Enterprise Risk $\begin{array}{lllll}\text { Management } & - & \text { Integrated } & \text { Framework. } & \text { Retrieved }\end{array}$ https://www.coso.org/Documents/COSO-ERM-Executive-Summary.pdf

Diamantopoulos, A., Sarstedt, M., Fuchs, C., Wilczynski, P., \& Kaiser, S. (2012). Guidelines for choosing between multi-item and single-item scales for construct measurement: A predictive validity perspective. Journal of the Academy of Market Science, 40(3), 434-449. https://doi.org/10.1007/s11747-011-0300-3

Dijkstra, T. K., \& Henseler, J. (2015). Consistent Partial Least Squares Path Modelling. MIS Quarterly, 39(2), 297-316.

Financial Stability Board. (2014). Guidance on Supervisory Interaction with Financial Institutions on Risk Culture: A Framework for Assessing Risk Culture. Retrieved from https://www.fsb.org/wp-content/uploads/140407.pdf

Fornell, C. G., \& Larcker, D. F. (1981). Evaluating Structural Equation Models with Unobservable Variables and 
Measurement Error," Journal of Marketing Research, 18(1), 39-50. https://doi.org/10.1177/002224378101800104

Franke, G., \& Sarstedt, M. (2019). Heuristics versus statistics in discriminant validity testing: A comparison of four procedures. Internet Research, 29(3), 430-447. https://doi.org/10.1108/IntR-12-2017-0515

Gatzert, N., \& Martin, M. (2015). Determinants and Value of Enterprise Risk Management: Empirical Evidence from the Literature. Risk Management and Insurance Review, 18(1), 29-53. https://doi.org/10.1111/rmir.12028

Gefen, D., \& Straub, D. (2005). A Practical Guide to Factorial Validity Using PLS-Graph: Tutorial and Annotated Example. Communications of the Association for Information Systems, 16(1), 91-109.

Gefen, D., Rigdon, E. E., \& Straub, D. (2011). An Update and Extension to SEM Guidelines for Administrative and Social Science Research. MIS Quarterly, 35(2)3-15. https://doi.org/10.2307/23044042

Geisser, S. (1974). A Predictive Approach to the Random Effects Model. Biometrika, 6(1), 101-107.

Ghazali, Z., \& Manab, N. A. (2013). Enterprise Risk Management and Value Creation: Initial Findings Amongst Non-Financial Public Listed Companies in Malaysia Bourse. Asian Economic and Financial Review, 3(7), 913-922. Retrieved from http://aessweb.com/journal-detail.php?id=5002

Golshan, N., \& Rasid, S. (2012). Determinants of Enterprise Risk Management Adoption: An Empirical Analysis of Malaysian Public Listed Firms. International Journal of Social and Human Sciences, 6, 119-126.

Gudergan, S. P., Ringle, C. M., Wende, S., \& Will, A. (2008). Confirmatory Tetrad Analysis n PLS Path Modeling. Journal of Business Research, 61(12), 1238-1249. https://doi.org/10.1016/j.jbusres.2008.01.012

Hair, J. F., Hult, G. T. M., Ringle, C. M., \& Sarstedt, M. (2017). A Primer on Partial Least Squares Structural Equation Modeling (PLS-SEM) (2nd ed.). Thousand Oaks. SAGE.

Hair, J. F., Ringle, C. M., \& Sarstedt, M. (2011). PLS-SEM: Indeed, a Silver Bullet. Journal of Marketing Theory and Practice, 19(2), 139-151. https://doi.org/10.2753/MTP1069-6679190202

Hair, J. F., Ringle, C. M., \& Sarstedt, M. (2013). Partial Least Squares Structural Equation Modeling: Rigorous Applications, Better Results, and Higher Acceptance. Long Range Planning, 46(1-2), 1-12. Retrieved from ttps://ssrn.com/abstract $=2233795$

Hair, J. F., Risher, J. J., Sarstedt, M., \& Ringle, C. M. (2019). When to Use and How to Report the Results of PLS-SEM. European Business Review, 31(1), 2-24. https://doi.org/10.1108/EBR-11-2018-0203

Hair, J. F., Sarstedt, M., Hopkins, L., \& Kuppelwieser. (2014). Partial Least Squares Structural Equation Modeling: An Emerging Tool in Business Research. European Business Review, 26(2), 106-121. https://doi.org/10.1108/EBR-10-2013-0128

Hamid M. R., Ab. Sami, W., \& Sidek, M. H. M. (2017). Discriminant Validity Assessment: Use of Fornell \& Larcker criterion versus HTMT criterion. Journal of Physics: Conference Series 890. https://doi.org/10.1088/1742-6596/890/1/012163

Hayduk, L. A., \& Littvay, L. (2012). Should researchers use single indicators, best indicators, or multiple indicators in structural equation models? BMC Medical Research Methodology, Retrieved from http://www.biomedcentral.com/147-2288/12/159

Henseler, J., \& Sarstedt, M. (2013). Goodness-of-fit Indices for Partial Least Squares Path Modeling. Compute Stat, 28, 565-580. https://doi.org/10.1007/s00180-012-0317-1

Henseler, J., Dijkstra, T. K., Sarstedt, M., Ringle, C. M., Diamantopoulos, A., Straub, D. W., Ketchen Jr., D. J., Hair, J. F., Hult, G. T. M., \& Calantone, R. J. (2014). Common Beliefs and Reality About PLS.

Henseler, J., Hubona, G., \& Ray, P. A. (2016). Using PLS Path Modeling in New Technology Research: Updated Guidelines. Industrial Management and Data Systems, 116(1), 2-20. https://doi.org/10.1108/IMDS-09-2015-0382

Henseler, J., Ringle, C. M., \& Sarstedt, M. (2015). A New Criterion for Assessing Discriminant Validity in variance-based Structural Equation Modeling. Journal of Academy of Market Science, 43(1), 115-135. https://doi.org/10.1007/s11747-014-0403-8

Hoyt, R. E., \& Liebenberg, A. P. (2011). The Value of Enterprise Risk Management. The Journal of Risk \& Insurance, 78(4), 795-822. https://doi.org/10.1111/j.1539-6975.2011.01413.x 
Hoyt, R. E., \& Liebenberg, A. P. (2015). Evidence of the Value of Enterprise Risk Management. Journal of Applied Corporate Finance, 27(1), 41-47. https://doi.org/10.1111/jacf.12103

Hu, L. T., \& Bentler, P. M. (1999). Cut off Criteria for Fit Indexes in Covariance Structure Analysis: Conventional Criteria versus New Alternatives. Structural Equation Modeling: A Multidisciplinary Journal, $6(1), 1-55$.

Institute of Risk Management. (2012). Risk Culture Resources for Practitioners. Retrieved from https://www.iia.org.uk/media/329076/irm_risk_culture___resources_for_practitioners.pdf

Jankensgård, H. (2019). A Theory of Enterprise Risk Management. Corporate Governance (Bingley), 19(3), 565-579. https://doi.org/10.1108/CG-02-2018-0092

Kimbrough, R. L., \& Componation, P. J. (2015). The Relationship Between Organizational Culture and Enterprise Risk Management. Engineering Management Journal, 21(2), 18-26. https://doi.org/10.1080/10429247.2009.11431803

Kleffner, A. E., Lee, R. B., \& McGannon, B. (2003). The Effect of Corporate Governance on the use of Enterprise Risk Management: Evidence from Canada. Risk Management and Insurance Review, 6(1), 53-73. https://doi.org/10.1111/1098-1616.00020

Kock, N. (2015). Common Method Bias in PLS-SEM: A Full Collinearity Assessment Approach. International Journal of e-Collaboration, 11(4), 1-10. https://doi.org/10.4018/ijec.2015100101

Kock, N., \& Hadaya, P. (2018). Minimum Sample Size Estimation in PLS-SEM: The inverse square root and gamma-exponential methods," Information Systems Journal, 28(1), 227-261. https://doi.org/10.1111/isj.12131

Kopia, J., Just, V., Geldmacher, W., \& Bubian, A. (2017). Organization Performance and Enterprise Risk Management. ECOFORUM, 6(1).

KPMG Government Institute. (2018). Your risk culture: An ERM enabler or barrier. Retrieved from https://institutes.kpmg.us/content/dam/institutes/en/government/pdfs/2018/risk-culture-erm.pdf

Lechner, P., \& Gatzert, N. (2017). Determinants and Value of Enterprise Risk Management: Empirical Evidence from Germany", The European Journal of Finance, 24(10), 867-887. https://doi.org/10.1080/1351847X.2017.1347100

Li, Q., Wu, Y., Ojiako, U., Marshall, A., \& Chipulu, M. (2014). Enterprise Risk Management and Firm Value within China's Insurance Industry. Acta Commercii, 14(1), 1-10. https://dx.doi.org/10.4102/ac.v14i1.198

Lundqvist, S. A. (2014). An Exploratory Study of Enterprise Risk Management: Pillars of ERM. Journal of Accounting, Auditing \& Finance, 29(3), 393-429. https://jaf.sagepub.com/content/29/3/393

Marshall, A. (2016). Why Risk Cultures Need Prudence. Centre for Risk Research, University of Southampton. Retrieved from https://eprints.soton.ac.uk/398719/1/_soton.ac.uk_UDE_PersonalFiles_Users_am2e08_mydocuments_rese $\operatorname{arch} \% 2520$ articles_2016\%2520papers_Prudence_63348_A4_20pp_RiskCulture_v4_WEB.pdf

Maruhun, E. N. S. M., Atan, R., Yusuf, S. N. S., \& Said, J. (2018). Developing Enterprise Risk Management Index for Shariah-Compliant Companies. Global Journal Al Thaqafah, 189-205.

Memon, M. A., Ting, H., Cheah, J. H., Ramayah, T., Chuah, F., \& Cham, T. H. (2020). Sample Size for Survey Research: Review and Recommendations". Journal of Applied Structural Equation Modelling, 4(2), 1-20. https://doi.org/10.47263/JASEM.2(1)01

Mikes, A., \& Kaplan, R. S. (2015). When One Size Doesn't Fit All: Evolving Directions in the Research and Practice of Enterprise Risk Management. Journal of Applied Corporate Finance, 27(1), 37-40. https://doi.org/10.1111/jacf.12102

Pagach, D., \& Warr, R. (2010). The Effects of Enterprise Risk Management on Firm Performance. Retrieved from https://papers.ssrn.com/sol3/papers.cfm?abstract_id=1155218

Pagach, D., \& Warr, R. (2011). The Characteristics of Firms that hire Chief Risk Officers. Journal of Risk and Insurance, 78(1), 185-211. https://doi.org/10.1111/j.1539-6975.2010.01378.x

Ping, T. A., \& Muthuveloo, R. (2015). The Impact of Enterprise Risk Management on Firm Performance: Evidence from Malaysia. Asian Social Science, 11(22), 149-159. https://doi.org/10.5539/ass.v11n22p149

Ringle, C. M., Wende, S., \& Becker, J. M. (2015). SmartPLS 3. Boenningstedt: SmartPLS. Retrieved from 
http://www.smartpls.com

Roslan, A., \& Dahan, H. M. (2013). Mediating Effects of Enterprise Risk Management Practices on Risk Culture and Organizational Performance. Retrieved from https://web.actuaries.ie/sites/default/files/erm-resources/092_-_azreen_-_mediating_effect_of_enterprise_ris k_management_practices_on_risk_culture_and_organizational_performance.pdf

Sarstedt, M., Hair, J. F., Cheah, J. H., \& Becker, J. M. (2019). How to specify, estimate, and validate higher-order constructs in PLS-SEM. Australian Marketing Journal. Retrieved from https://doi.org/10/1016/j.ausmj.2019.05.003

Sarstedt, M., Ringle, C. M., \& Hair, J. F. (2017). Partial Least Squares Structural Equation Modeling. In Homburg C, Klarmann, M, Vomberg A (Eds.), Handbook of Market Research (pp. 1-40).

Sax, J., \& Andersen, T. J. (2019). Making Risk Management Strategic: Integrating Enterprise Risk Management with Strategic Planning. European Management Review, 16(3), 719-740. https://doi.org/10.1111/emre.12185

Sayilir, O., \& Farhan, M. (2017). Enterprise Risk Management and its Effect on Firm Value in Turkey. Journal of Management Research, 9(1), 86-99.

Selamat, M. H., \& Ibrahim, O. (2018). The Moderating Effect of Risk Culture in Relationship between Leadership and Enterprise Risk Management in Malaysia. Business Management and Strategy, 9(1), 244-271. https://doi.org/10.5296/bms.v9i1.12140

Sheedy, E. A., \& Jepsen, D. (2018). How to Measure Risk Culture in Australian Superannuation Funds. Macquarie University Faculty of Business \& Economics Research Paper. Retrieved from https://papers.ssrn.com/sol3/papers.cfm?abstract_id=3128693

Soliman, A., \& Adam, M. (2017). Enterprise Risk Management and Firm Performance: An Integrated Model for the Banking Sector. Banks and Bank Systems, 12(2). https://doi.org/10.21511/bbs.12(2).2017.12

Stone, M. (1974). Cross-validatory Choice and Assessment of Statistical Predictions. Journal of the Royal Statistical Society, 36(2), 111-147. https://www.jstor.org/stable/2984809

Stultz, R. M. (2016). Risk Management, Governance, Culture, and Risk-Taking in Banks. FRBNY Economic Policy Review, 22(1), 43-60. https://ssrn.com/abstract-2828073

Teo, T., Su Luan, W., \& Sing, C. C. (2008). A cross-cultural examination of the intention to use technology between Singaporean and Malaysian pre-service teachers: an application of the Technology Acceptance Model (TAM). Educational Technology \& Society, 11(4), 265-280.

Viscelli, T. R., Beasley, M. S., \& Hermanson, D. R. (2016). Research Insights About Risk Governance: Implications from a Review of ERM Research. Sage Open, 1-17. Retrieved from http://journals.sagepub.com/doi/pdf/10.1177/2158244016680230

Waweru, N., \& Kisaka, E. S. (2013). The Effect of Enterprise Risk Management Implementation on the Value of Companies Listed on the Nairobi Stock Exchange. Retrieved from http://ssrn.com/abstract=1907248 


\begin{tabular}{|c|c|c|c|}
\hline Variable & Description & Variable & Description \\
\hline EG1 & Exercise Board Risk Oversight & RDT3 & After Treatment of Whistle Blowers \\
\hline EG2 & Establishment of Operating Structures & RGA1 & Clear Specific Risk Management \\
\hline EG3 & Definition of Desired Risk Culture & RGA2 & Clear Risk Management Process \\
\hline EG4 & Demonstration of Commitment to Core Values & RGA3 & Documentation and Communication of Risks \\
\hline EG5 & Attracts, Develops, and Retains Capable Individuals & RGA4 & Communication and Review Structures of Risk \\
\hline ES1 & Analyse Business Context & RGA5 & Risk Governance \\
\hline ES2 & Defines Risk Appetite & RGR1 & Transparent Risk Information \\
\hline ES3 & Evaluate Alternative Strategies & RGR2 & Strategic Direction for Risk Taking \\
\hline ES4 & Formulate Business Objectives & RGR3 & Celebration of Successful Risk Taking \\
\hline EP1 & Identification of Risks & RGR4 & Learning from Inappropriate Risk taking \\
\hline EP2 & Assessment of Severity of Risks & RDI1 & Timely and Transparent Risk Information \\
\hline EP3 & Risk Prioritisation & RDI2 & Determination of Boundaries and Risk Appetite \\
\hline EP4 & Implementation of Risk Responses & RDI3 & Risk Integration into Decision Making \\
\hline EP5 & Development of Risk Portfolio & RDR1 & Reward for Appropriate Risk Taking \\
\hline ER1 & Assessment of Substantial Changes & RDR2 & Sanction for Inappropriate Risk Taking \\
\hline ER2 & Revision of Risk and Performance & RDR3 & Value and Nurturing Appropriate Behaviours \\
\hline ER3 & Pursuit of improvement in ERM & RDR4 & Performance Management of Risk Competency \\
\hline EI1 & Leverage on IT to support ERM & RCR1 & Risk Function Access to Senior Management \\
\hline EI2 & Communication Channels to support ERM & RCR2 & Credibility of Risk Function \\
\hline EI3 & Reporting on Risk, Culture and Performance & RCR3 & Required Resources for the Risk Function \\
\hline RTR1 & Presence of Distinct Tone at the Top & RCR4 & Risk Function Discussions of Key Risks \\
\hline RTR2 & Provision of Direction to Risk Management & RCR5 & Support of Risk Function \\
\hline RTR3 & Visible, Consistent and Sustained Commitment & RCS 1 & Risk Competency and Capability as Key Assets \\
\hline RTR4 & Executive Sponsor of Risk Management & RCS2 & Awareness of Internal Controls \\
\hline RTR5 & Tangible Actions of Executive Sponsor & $\mathrm{RCS} 3$ & Management of "Concern for Risk"/ "Risk Awareness" \\
\hline RTD1 & Encourage Risk Information and "Bad News" & RCS4 & Encouragement and Development of Risk Skills \\
\hline RDT2 & Support and Celebrate Whistle Blowers & & \\
\hline
\end{tabular}

\section{Copyrights}

Copyright for this article is retained by the author(s), with first publication rights granted to the journal.

This is an open-access article distributed under the terms and conditions of the Creative Commons Attribution license (http://creativecommons.org/licenses/by/4.0/). 